\title{
The Unmaking of a Modern Synthesis: Noam Chomsky, Charles Hockett, and the Politics of Behaviorism, 1955-1965
}

Gregory Radick, University of Leeds

\begin{abstract}
A familiar story about mid-twentieth-century American psychology tells of the abandonment of behaviorism for cognitive science. Between these two, however, lay a scientific borderland, muddy and much traveled. This essay relocates the origins of the Chomskyan program in linguistics there. Following his introduction of transformational generative grammar, Noam Chomsky (b. 1928) mounted a highly publicized attack on behaviorist psychology. Yet when he first developed that approach to grammar, he was a defender of behaviorism. His antibehaviorism emerged only in the course of what became a systematic repudiation of the work of the Cornell linguist C. F. Hockett (19162000). In the name of the positivist Unity of Science movement, Hockett had synthesized an approach to grammar based on statistical communication theory; a behaviorist view of language acquisition in children as a process of association and analogy; and an interest in uncovering the Darwinian origins of language. In criticizing Hockett on grammar, Chomsky came to engage gradually and critically with the whole Hockettian synthesis. Situating Chomsky thus within his own disciplinary matrix suggests lessons for students of disciplinary politics generally and-famously with Chomsky — the place of political discipline within a scientific life.
\end{abstract}

\section{WHY ANTIBEHAVIORISM? WHY CHOMSKY'S?}

Anyone inclined to organize the history of science around "revolutions" has long had to hand a tidy scheme for dividing up American psychology in the twentieth century. Before World War II there was the behaviorist revolution. After the war there was the cognitive revolution. Where the former banished the mind from the domain of psychological knowledge, the latter brought it back in. Each revolution's beginnings, moreover, have an emblem in a brilliant, boldly controversial call to arms: on the one side, John Watson's 1913 manifesto "Psychology as

School of Philosophy, Religion, and History of Science, University of Leeds, Leeds LS2 9JT, United Kingdom; g.m.radick @leeds.ac.uk. This paper has benefited enormously from discussions at seminars and meetings in Leeds, Lancaster, Vancouver, Berlin, and Edinburgh and from the improving attention of a small army of learned readers and listeners, including Jonathan Hodge, Paul Strand, Jamie Cohen-Cole, Tammy Goss, John Joseph, Tania Munz, Randy Harris, Michael Gordin, Geoffrey Pullum, Steven Pinker, Ageliki Lefkaditou, Floris Cohen, and the Isis referees. It is a pleasure to thank them all for their muchappreciated generosities.

Isis, volume 107, number 1. (C) 2016 by The History of Science Society.

All rights reserved. 0021-1753/2016/0107-0003\$10.00. 
the Behaviorist Views It"; on the other, Noam Chomsky's 1959 mauling of the neobehaviorist B. F. Skinner's Verbal Behavior (1957). ${ }^{1}$

Along with this two-revolutions picture came, by the early 1990s, a historiography that went some way toward illuminating the timing, personnel, and institutional geography of the changeover. It taught, among other things, about the role of the war effort in bringing psychologists and engineers into collaboration; the surge to prominence after the war of computers, information theory, and cybernetics; the growing dissatisfaction, in and out of psychology, with behaviorism and, in its "neo-" phase, the positivist philosophy of science increasingly allied to it; the new willingness among some psychologists, in the wake of these developments, to investigate cognitive processes using engineers' concepts and language; the encouragement of this interdisciplinary research by deep-pocketed foundations aligned with larger Cold War agendas; the emergence of Cambridge, Massachusetts, as a home for the new research; and epoch-making publications from the likes of Jerome Bruner, George Miller, and, of course, Chomsky, later to become one of the most globally famous intellectuals of the age. ${ }^{2}$

As with regime changes in science generally, however, this one looked less than total when examined close up. Behaviorism after Watson covered a range of positions, some of them remarkably close to its supposedly negating successor. The Berkeley comparative psychologist Edward Tolman bowed to no one in his estimate of the value for human psychology of observing the learning behavior of white rats in mazes; yet he summed up that research in 1932 under the mental-mechanical title Purposive Behavior in Animals and Men. ${ }^{3}$ Later, when behaviorism came to seem old-fashioned in psychology departments, it thrived in clinics, as it continues to do. ${ }^{4}$ It even survives conceptually, and crucially, within theoretical cognitive science, in the form of the Turing test's denial of a distinction between artificial intelligence and its simulation. ${ }^{5}$ More and more, historians and other commentators alert to such difficulties, and also to the

\footnotetext{
${ }^{1}$ John Watson, "Psychology as the Behaviorist Views It," Psvchological Review, 1913, 13:158-177; and Noam Chomsky, rev. of B. F. Skinner, Verbal Behavior, Language, 1959, 35:26-58. On their positions within the relevant revolutions see, e.g., Bernard J. Baars, The Cognitive Revolution in Psychology (New York: Guilford, 1986), pp. 41, 141. For an overview see, e.g., Sigmund Koch's foreword to A Century of Psychology as Science, ed. Koch and David E. Leary (1985; Washington, D.C.: American Psychological Association, 1992), pp. 7-35, esp. pp. 25-26.

${ }^{2}$ On Chomsky's status as both a "citation champ" (just behind Freud and Hegel) and the "world's top public intellectual" in a 2005 poll see the articles in, respectively, MIT Tech Talk, 15 Apr. 1992, http://newsoffice.mit.edu/1992/citation-0415; and the Guardian, 18 Oct. 2005, http://www.theguardian.com/world/2005/oct/18/books.higher education. For a summary of the historiographic state of the art around the time of the former see Roger Smith, The Fontana History of the Human Sciences (London: Fontana, 1997), pp. 832-842, 1003-1005. The major specialist study besides Baars, Cognitive Revolution in Psychology, which includes interviews with many of the founding figures, was Howard Gardner, The Mind's New Science: A History of the Cognitive Revolution (1985; New York: Basic, 1987).

${ }^{3}$ Baars labeled Tolman's psychology "cognitive behaviorism”: Baars, Cognitive Revolution in Psychology, pp. 61-62, on p. 61. See Edward C. Tolman, Purposive Behavior in Animals and Men (New York: Appleton-Century-Crofts, 1932); and Robert Boakes, From Darwin to Behaviourism: Psychology and the Minds of Animals (Cambridge: Cambridge Univ. Press, 1984), pp. 230-236. For a superb brief historical survey of behaviorism, including the role of Chomsky's Skinner review in its decline, see Roger Smith, "Behaviourism," in Companion to the History of Modern Science, ed. R. C. Olby, G. N. Cantor, J. R. R. Christie, and M. J. S. Hodge (London: Routledge, 1990), pp. 410-423. On why behaviorism was not, according to once-standard definitions, revolutionary - and cognitive science even less so - see Thomas H. Leahey, "Mythical Revolutions in American Psychology, American Psychologist, 1992, 47:308-318

${ }^{4}$ On "the triumph of behaviorism in the clinic" see Baars, Cognitive Revolution in Psychology, pp. 143-144, on p. 144. Outside the clinic, Skinnerian behaviorism has entered many homes via a best-selling self-help book: Karen Pryor, Don't Shoot the Dog! The New Art of Teaching and Training (Dorking, Surrey: Ringpress, 2008).

${ }^{5}$ This foundational issue rose to the surface in the 1980s debate over John Searle's "Chinese Room" argument against "AI" and the response to it by Daniel Dennett, a career-long philosophical champion of cognitive science. On Dennett's philosophy of mind as "a sophisticated version of Rylean behaviourism" see Matthew Elton, Daniel Dennett: Reconciling Science and Our Self-Conception (Oxford: Polity, 2003), pp. 274-275. For Searle versus Dennett (and many others) on the Chinese Room argu-
} 
problematic status of "revolution" talk (so often a legacy of partisans), have produced detailed studies of the paths that led the pioneers of what became cognitive science to distance themselves from what they regarded as behaviorism. Out of these studies have come new perspectives not only on the borderland between behaviorism and cognitive science but on the whole of the postwar human sciences. ${ }^{6}$

Here I want to show how Chomsky - conspicuous by his absence so far from this "continuationist" historiography - likewise came to his antibehaviorism in a protracted way, for reasons whose recovery can pay dividends for historians today. Several times over, the version of Chomsky's story that will follow challenges the familiar one, which goes roughly like this. Largely in isolation from the work then dominant in American linguistics, the young Chomsky developed a new analysis of grammar whose explosive implications for behaviorism he well understood but kept under wraps in the book introducing that analysis, Syntactic Structures (1957). Emboldened, however, by the book's favorable reception, Chomsky - still in his late twenties, and only recently appointed to what would become a career-long position at MIT-used the opportunity to review Verbal Behavior to go public with those behaviorism-undermining implications. From that point he continued to reveal further, far-reaching implications of his technical work on grammar for the science of language and mind. ${ }^{7}$

The proposed revisions, in brief, are as follows. A close study of Chomsky's writing at the end of his period as a Junior Fellow at Harvard (1951-1955) suggests that, far from expressing a deep animus toward behaviorist psychology, he endorsed it at this time, treating it not just as scientifically sensible but as straightforwardly compatible with the analysis of grammar he would shortly publish in Syntactic Structures. His coming to hold the reverse of this position thus represents a major shift on his part-a shift that, furthermore, can be dated as taking place between the summer of 1956, when he sent Syntactic Structures to the press, and the autumn of 1958, when he submitted that long, lacerating review. As we shall see, behaviorism became troublesome for Chomsky only as he came to appreciate its status among fellow American linguists as supporting an analysis of grammar different from, and to a certain extent competing with, his own. What Chomsky championed was what would eventually be known as "transformational generative grammar." What he rejected was what he called a "communicationtheoretic" grammar, which he identified with the Cornell linguist Charles Hockett.

ment see John Searle, "Minds, Brains, and Programs," Behavioral and Brain Sciences, 1980, 3:417-457, esp. pp. 428-430 for Dennett's reply.

${ }^{6}$ See, e.g., Peter Galison, "The Ontology of the Enemy: Norbert Wiener and the Cybernetic Vision," Critical Inquiry, 1994, 21:228-266, esp. pp. 245-252; Galison's remarks in Sina Najafi and Galison, "The Ontology of the Enemy: An Interview with Peter Galison," Cabinet, 2003, online edition available at http://cabinetmagazine.org/issues/12/najafiz.php; Hunter CrowtherHeyck, "George A. Miller, Language, and the Computer Metaphor of Mind," History of Psychology, 1999, 2:37-64; CrowtherHeyck, Herbert A. Simon: The Bounds of Reason in Modern America (Baltimore: Johns Hopkins Univ. Press, 2005), esp. Ch. 11; Lily E. Kay, "From Logical Neurons to Poetic Embodiments of Mind: Warren S. McCulloch's Project in Neuroscience," Science in Context, 2001, 14:591-614; and Tara H. Abraham, "Transcending Disciplines: Scientific Styles in Studies of the Brain in Mid-Twentieth-Century America," Studies in History and Philosophy of Biological and Biomedical Sciences, 2012, 43:552-568. On "revolution" talk and its discontents, the debate among historians of linguistics in the 1980s over whether Chomsky fomented one can be sampled in Frederick J. Newmeyer, “Has There Been a ‘Chomskyan Revolution’ in Linguistics?” Language, 1986, 62:1-18; and E. F. K. Koerner, “The Chomskyan 'Revolution' and Its Historiography: Observations of a Bystander," in Practicing Linguistic Historiography (Amsterdam: Benjamins, 1989), pp. 101-146. For more recent reflections from a range of perspectives see the Festschrift for Koerner: Douglas A. Kibbee, ed., Chomskyan (R)evolutions (Amsterdam: Benjamins, 2010).

${ }^{7}$ See, e.g., the interview with Chomsky in Baars, Cognitive Revolution in Psychology (cit. n. 1), pp. 341-351; and Gardner, Mind's New Science (cit. n. 2), pp. 189-196. 
Thirteen years older than Chomsky, Hockett was widely regarded as the successor to Leonard Bloomfield, the main progenitor of American structural linguistics. ${ }^{8}$ Bloomfield was a behaviorist, and so was Hockett-vociferously so. It was Hockett who linked an approach to grammar based on the then-new statistical theory of communication with a behaviorist, stimulus-response account of language acquisition. As Chomsky came, gradually, to conceptualize communication-theoretic grammar as what his rule-based, transformational generative grammar improved on, he came to conceive of stimulus-response behaviorism as needing replacement as well; he also became convinced that an innatist stance on how children acquire language was a much better fit with his stance on grammar than anything to be found in stimulus-response learning theory. His review of Verbal Behavior became the occasion for this second strike at the linguistics whose chief spokesman was Hockett. A number of otherwise peculiar features of the review make sense when it is seen as pitched at least as much against Hockett's Bloomfieldian behaviorism as against Skinner's rather different behaviorism.

This alternative view of Chomsky, as launched from the mid to late 1950s on a comprehensive repudiation of positions that Hockett, distinctively, had put together, has the further merit of resolving a long-standing puzzle about the Chomskyan program. Even admirers of that program have often wondered why Chomsky, from the 1960s until quite recently, took such a dim view of the prospects of gaining insight into language from studies of animal communication or attempts to draw on those studies in theorizing about the evolutionary origins of language. ${ }^{9}$ Again, Hockett's role as exponent of what Chomsky came to be against proves illuminating. Hockett was one of a sizable group of structural linguists who backed behaviorism, though no one else backed it more strongly. He was one of a smaller group who took a positive interest in statistical communication theory, though no one else did more to promote it or to develop it within linguistics. But he was unique in calling for linguists to embrace modern animal communication studies and Darwinian theory and showing them how to do so. His own much-discussed "design features" approach to thinking about comparative-evolutionary questions about language is often all that many linguists nowadays ever learn of his work.

Most of what follows will dwell on Chomsky's engagements with that work in the period from 1955 to 1965. Near the end, however, I want to look farther back and consider Hockett's motives for supplementing the behaviorism he acquired in the 1930s as Bloomfield's reader and student with those innovations of the 1940s, information theory and the gradualist Darwinism of the modern synthesis. Chomsky may not have had a plan for his program; but Hockett certainly had one for his. He made it his mission, starting in the late 1940s, and in the name of the Unity of Science movement, to unify behaviorist linguistics with the new evolutionary biology and so squeeze out once and for all any lingering vitalism and "mentalism." Remarkably enough, he dubbed this endeavor "sociobiology."10 When Hockett published his sociobiologi-

\footnotetext{
${ }^{8}$ On Hockett as the "Bloomfieldian boy-wonder," "the Bloomfieldian-most-likely," and the "master's favored son" see Randy A. Harris, The Linguistics Wars (Oxford: Oxford Univ. Press, 1993), pp. 43, 53. On American structural linguistics between Bloomfield's era and Chomsky's see ibid., Chs. 2 and 3.

${ }^{9}$ The best-known Darwinian account of the Chomskyan "language organ" is in Steven Pinker, The Language Instinct: How the Mind Creates Language (London: HarperPerennial, 1995), esp. Ch. 11. On Chomsky's skepticism about the possibility of such an account as having "puzzled many readers" see ibid., p. 24. On his late-period embrace of evolutionary biolinguistics in exaptationist, evo-devo mode see W. Tecumseh Fitch, "Noam Chomsky and the Biology of Language," in Outsider Scientists: Routes to Innovation in Biology, ed. Oren Harman and Michael R. Dietrich (Chicago: Univ. Chicago Press, 2013), pp. 201-222. ${ }^{10}$ For discussion of Hockett's use of the term around the same time that J. P. Scott and T. C. Schneirla used it in connection with the study of animal social behavior-disciplinary home to the term's most famous promoter, E. O. Wilson - see Charlotte Sleigh, Six Legs Better: A Cultural History of Myrmecology (Baltimore: Johns Hopkins Univ. Press, 2007), p. 195.
} 
cal manifesto in 1948, information theory, itself just being published, was not included. But on encountering it, he made room for the theory in the program, relishing the potential he saw in the mathematics of communication for advancing the cause of reductionist unification (a humanist cause, as he understood it).

\section{HOCKETT'S GRAMMAR AS A FOIL FOR \\ TRANSFORMATIONAL GENERATIVE GRAMMAR}

It is well to begin with an overview of Syntactic Structures. "Grammar" there means a theory or model of the construction of grammatical sentences. One aim of the book was to identify criteria for favoring one candidate grammar, in this sense, over another. In Chomsky's view, at a minimum, a grammar ought to be capable of generating all, and only, the grammatically possible sentences in a given natural language. Ideally, however, this requirement of empirical adequacy would be met with the simplest of theoretical means and in a way that illuminated linguistic structure more generally. A related aim was to develop a criteria-fulfilling grammar for a particular language, English. To this end the book expounded three such grammars in succession, each more powerful than the last. First was a grammar based on what Chomsky called an "elementary communication-theoretic model for language," arising from the recently fashionable information theory of Claude Shannon and Warren Weaver. Chomsky made quick work of this beads-on-a-string approach to word order, arguing that it could never meet even his minimal requirement. Next came a grammar analyzing sentences into structured phrases, themselves analyzed down to constituent parts of speech, with the whole process of analysis being formulated as a set of rules. This "phrase-structure grammar" did manage the minimum; but, given the cumbersome nature of some of its analyses, it did so inelegantly, Chomsky judged. His solution was the third grammar, his "transformational grammar": phrase-structure grammar for basic sentences, supplemented by rules for transforming its analyses to generate other, variant sentences as needed. Here, as he saw it, were empirical adequacy and simplicity, but also a source of new insights, as hitherto unsuspected patterns revealed themselves at the transformational level. ${ }^{11}$

Hockett's main appearance in the text was as an exponent of the least impressive of grammars, the communication-theoretic, and, more generally, of the statistical approach that grammar embodied. Quoting in the early pages of Syntactic Structures from Hockett's 1955 book A Manual of Phonology, Chomsky wrote:

It is natural ... to assume that the linguist's sharp distinction between grammatical and ungrammatical is motivated by a feeling that since the "reality" of language is too complex to be described completely, he must content himself with a schematized version replacing "zero probability, and all extremely low probabilities, by impossible, and all higher probabilities by possible." We see, however, that this idea is quite incorrect, and that a structural analysis cannot be understood as a schematic summary developed by sharpening the blurred edges in the full statistical picture.

\footnotetext{
${ }^{11}$ Noam Chomsky, Syntactic Structures (The Hague: Mouton, 1957), p. 20. On the book's origins and reception see Harris, Linguistics Wars (cit. n. 8), pp. 28-54; Pieter Seuren, “Concerning the Roots of Transformational Generative Grammar," Historiographia Linguistica, 2009, 36:97-115; and Stephen O. Murray, Theory Groups and the Study of Language in North America: A Social History (Amsterdam: Benjamins, 1994), Ch. 9. For the biographical basics on Chomsky, a good place to start is the collection of reference articles freely downloadable from his website: http://www.chomsky.info/bios.htm. A hagiographical but nevertheless useful book-length study is Robert F. Barsky, Noam Chomsky: A Life of Dissent (Cambridge, Mass.: MIT Press, 1997).
} 


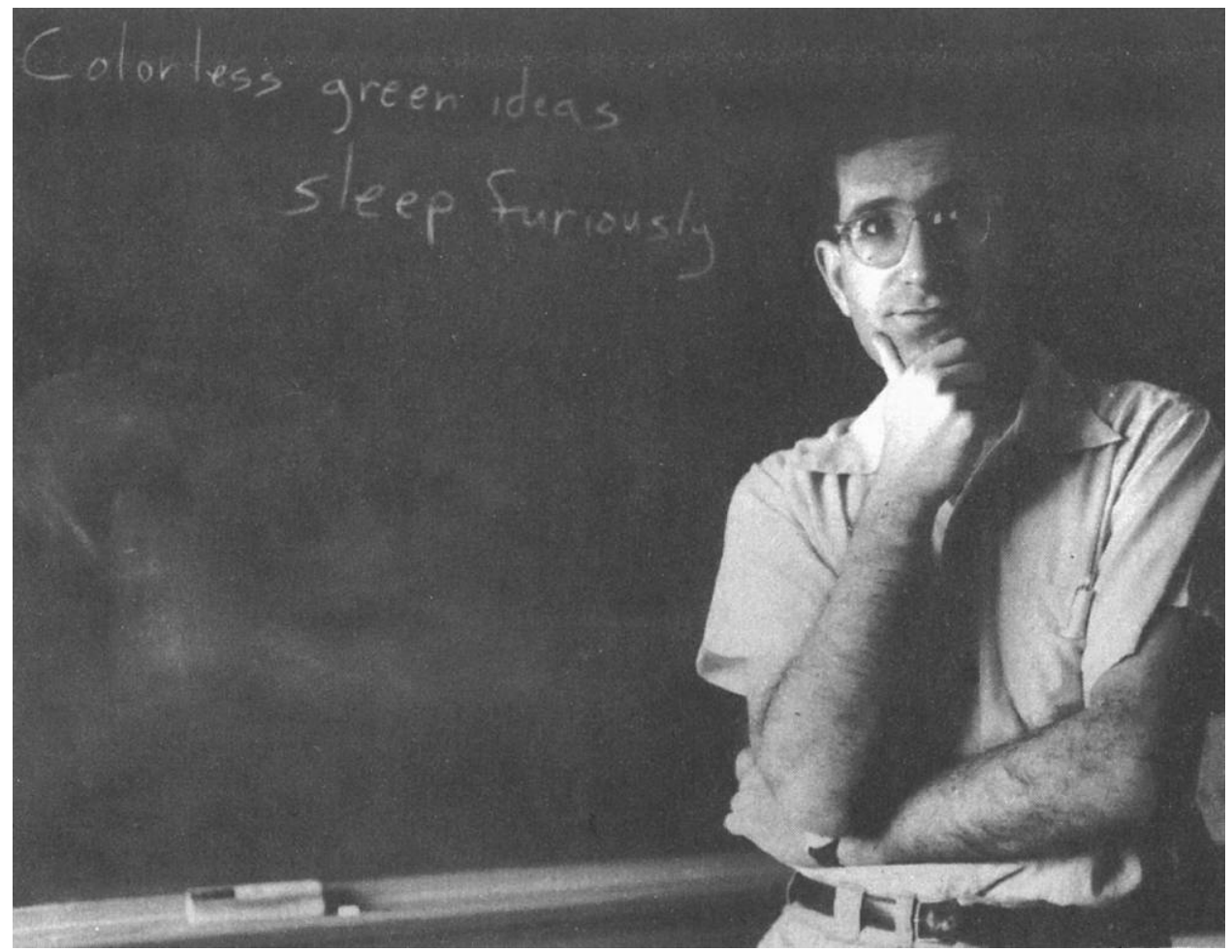

Figure 1. Noam Chomsky at the Institute for Advanced Study in Princeton in 1959. From Robert F. Barsky, Noam Chomsky: A Life of Dissent (Cambridge, Mass.: MIT Press, 1997), p. 92.

That incorrectness had been borne home in part with help from Chomsky's most famous oneliner, "Colorless green ideas sleep furiously" (see Figure 1). Best known as an example of a sentence that is nonsensical yet grammatical, in line with the Chomskyan notion that grammar has nothing to do with semantics, it did further duty as an improbable yet grammatical sentence and, so, as evidence that grammar has nothing to do with probability. A few pages along, having elaborated the full communication-theoretic account, including its conception of the speaker as a machine with a finite number of internal, symbol-producing states, transitions between which were assigned different probabilities, Chomsky added a note: "This is essentially the model of language that Hockett develops in A Manual of Phonology." 12

Up to a point, the impression of Hockett that one takes from this part of Syntactic Structures - that he developed a model delineated in Shannon and Weaver's Mathematical Theory of Communication (1949) - is accurate. It was there, in the ur-text of information theory, that Shannon and Weaver showed how the stringing together of words one by one into a grammatical sentence could be modeled statistically and represented with state diagrams, of the sort that Chomsky included to illustrate a finite-state grammar in action. But Shannon and Weaver never suggested that such a process takes place in the heads of grammatically speaking people,

\footnotetext{
${ }^{12}$ Chomsky, Syntactic Structures, pp. 16-17, quoting from p. 10 in Charles F. Hockett, A Manual of Phonology (Baltimore: Waverly, 1955) (emphases in Hockett's original); pp. 15-16 (regarding "Colorless green ideas sleep furiously"); p. 20 ("essentially the model").
} 
much less that their speech could usefully be considered the output of some kind of finite-state machine. ${ }^{13}$ Those moves were Hockett's. He first made them in a 1953 review of Shannon and Weaver's book in Language, the preeminent journal in the field. Surveying a range of linguistic applications that he foresaw for Shannon-Weaver information theory, he wrote, apropos of grammar (here called "tactics"): "Let us imagine a unit called a tactics box in the brain. The tactics box passes through a series of states." ${ }^{14}$ In A Manual of Phonology, published two years later, he enlarged the proposal and expanded its World War II-vintage military ambience, renaming the tactics box the "Grammatic Headquarters," or "G.H.Q.", and placing it within a larger mechanical system, composed of several linked subsystems: a "Phoneme Source," a "Morphemicizer," and so on. ${ }^{15}$

Throughout the mid 1950s, as Hockett staked out his position on grammar, that position gradually emerged for Chomsky as a productive foil for the presentation of his own ideas. Citations to the Shannon-Weaver review and A Manual of Phonology, among a number of other writings by Hockett, appear in Chomsky's massive Logical Structure of Linguistic Theory, completed in June 1955 (though with later edits). ${ }^{16}$ Although it formed the basis for Syntactic Structures, LSLT, as it is known, is not structured around the same three-stage ascent, from lowly finitestate grammar on up. Early on, there are discussions of grammaticalness as distinct from notions of probability, exemplified by the "Colorless green ideas" sentence, and footnotes disparaging Hockett's Manual as having confused matters. ${ }^{17}$ But the text mostly concerns phrase-structure and transformational grammars and so, more generally, the constituent-structure methods that had engaged Chomsky ever since he had encountered them in the work of his teacher at the University of Pennsylvania, Zellig Harris. In LSLT Chomsky did group the three grammars together in order to show that they formed a hierarchy, but he did so in an appendix to a middle chapter, on phrase structure. ${ }^{18}$ He brought this subsequently celebrated "Chomsky Hierarchy" to the fore only in 1956, at a famous symposium on information theory. His paper there, entitled

\footnotetext{
${ }^{13}$ Claude E. Shannon and Warren Weaver, The Mathematical Theory of Communication (Urbana: Univ. Illinois Press, 1949), pp. 39-48. Although George Miller took up these ideas, notably in his 1951 book Language and Communication, he too treated them as bearing not on the message generator - that would come later, from ca. 1955-but on the messages themselves. See Crowther-Heyck, "George A. Miller, Language, and the Computer Metaphor of Mind" (cit. n. 6), pp. 44-48, 52-56; and George A. Miller, Language and Communication (New York: McGraw-Hill, 1951).

${ }^{14}$ Charles F. Hockett, rev. of Claude E. Shannon and Warren Weaver, The Mathematical Theory of Communication, rpt. in Hockett, The View from Language: Selected Essays, 1948-1974 (Athens: Univ. Georgia Press, 1977), pp. 19-52, on p. 41 (first published in Language, 1953, 29:69-93) (subsequent citations will be to the reprinted version). In later life Chomsky credited an earlier and, in his view, "very perceptive" paper of Hockett's, "A Note on 'Structure'” (International Journal of American Linguistics, 1948, 14:269-271), with stating the more general "very strong realist" case for regarding the procedures of the grammaranalyzing linguist as representing what happens in the brain of the language-learning child. See Pierre Swiggers, "Grammar and Language in Syntactic Structures," in Chomskyan (R)evolutions, ed. Kibbee (cit. n. 6), pp. 215-233, esp. pp. $218-220$ (the quotations, from a 1977 interview, are on p. 219). See also Stephen R. Anderson, Phonology in the Twentieth Century (Chicago: Univ. Chicago Press, 1985), pp. 284-285.

${ }^{15}$ Hockett, Manual of Phonology (cit. n. 12), pp. 3-17, esp. pp. 4-5.

${ }^{16}$ Noam Chomsky, Logical Structure of Linguistic Theory, unpublished typescript, June 1955 (with handwritten annotations dated 1956) (hereafter cited as Chomsky, LSLT). The version I have studied is a scan of a Harvard-made microfilm with order no. 91920; my citations supply both Chomsky's identifying chapter and page numbers (e.g., "IV-153" refers to Ch. 4, p. 153) and the more convenient frame numbers. For citation of Hockett's review of Shannon and Weaver see IV-153, note 29 (frame 178); it is identified on IV-5 frn (frame 210). For citations of Hockett's Manual of Phonology see note 17, below.

${ }^{17}$ See Chomsky, LSLT, I-38 (frame 41), for the "Colorless green ideas" sentence. For citations to Hockett's Manual of Phonology see I-51, note 54 (frame 55), identified in a handwritten note on I- $8^{\text {ff }}$ (frame 74); I-59, note 60 (frame 64), identified on I-1 $0^{\text {fn }}$ (frame 76); and IV-14624' (frame 171), identified on IV-4fin (frame 209).

${ }^{18}$ Chomsky, LSLT, appendix to Chapter 6, VI-6 (frame 350) ff. On Chomsky in LSLT as extending Harris's work see the introduction to LSLT and, for a historical assessment, Bruce Nevin, "Noam and Zellig," in Chomskyan (R)evolutions, ed. Kibbee (cit. n. 6), pp. 103-168 - though, on the matter of behaviorism, see Seuren, "Concerning the Roots of Transformational Generative
} 
"Three Models for the Description of Language," featured what he characterized as a proof of the inability of a finite-state grammar in principle to model natural languages adequately. ${ }^{19}$ There was no reference to Hockett; but for linguists, familiar (as Chomsky was) with Hockett's wellknown earlier paper "Two Models of Grammatical Description" (1954), the one-upmanship in Chomsky's title was plain, as was its target. ${ }^{20}$

He took aim more explicitly in an extensive review, published in 1957, of A Manual of Phonology. For our purposes, several of his criticisms in particular bear emphasis. There was, unsurprisingly, an attack on the G.H.Q. model, mocked with the observation that, as demonstrated in the impossibility proof, "an infinite amount of equipment will be required to build Hockett's hardware G.H.Q." There were also criticisms to do with Hockett's claim that the G.H.Q. model supported Bloomfield's behaviorist, stimulus-response account of linguistic communication. An old problem with that account, Hockett explained, was the manifestly false determinism it posited between a speaking, understanding individual and his or her environment. In Hockett's view, the new model enabled those relationships to be glossed probabilistically, thus solving the problem. But Chomsky doubted it. For one thing, he noted, it would be hard to assess the truth of statements of the form " $\mathrm{X}$ will say $\mathrm{Y}$ in circumstance $\mathrm{C}$ with probability p," since such statements will always come with other-things-being-equal riders, rendering the statements empty ("X will say $\mathrm{Y}$ except when $\mathrm{X}$ will not say $\mathrm{Y}$ "). For another, he failed to see how the probabilistically enriched account could handle synonym pairs, in which words or expressions mean the same thing but sometimes have very different probabilities, such as active and passive expressions (an explanatory specialty of transformational grammar). But what seems to have provoked Chomsky above all were Hockett's animadversions against formal approaches, dismissed as "hocus-pocus." On the contrary, wrote Chomsky, the precise formulation and rigorous testing of hypotheses kept inquiry on the path of objectivity and would serve linguistics far better than the vagueness and intuition that, underneath its hardscience veneer, vitiated Hockett's work. ${ }^{21}$

Grammar" (cit. n. 11), pp. 103-106, who has the better of their argument. See also Nevin, "More Concerning the Roots of Transformational Generative Grammar," Hist. Ling., 2009, 36:459-479.

${ }^{19}$ Noam Chomsky, "Three Models for the Description of Language," IRE Transactions in Information Theory, 1956, IT-2:113124, esp. pp. 114-116; for discussion see Randy A. Harris, "Chomsky's Other Revolution," in Chomskyan (R)evolutions, ed. Kibbee, pp. 237-264, esp. pp. 253-255. On the 10-12 Sept. 1956 MIT symposium on information theory, and the case for the day Chomsky spoke as the birthday of cognitive science, see Gardner, Mind's New Science (cit. n. 2), pp. 28-29. On why Chomsky's claim to have provided a proof should, in hindsight, be resisted see Geoffrey K. Pullum, "Creation Myths of Generative Grammar and the Mathematics of Syntactic Structures," in The Mathematics of Language, ed. Christian Ebert, Gerhard Jäger, and Jens Michaelis (Dordrecht: Springer, 2010), pp. 238-254, esp. pp. 242-244.

${ }^{20}$ Charles F. Hockett, "Two Models of Grammatical Description," Word, 1954, 10:210-234, cited in Chomsky, LSLT, I-50, note 51 (frame 54), identified on I-7 fin (frame 73), and in Chomsky, Syntactic Structures (cit. n. 11), pp. 41, 50. See Noam Chomsky, "Of Minds and Language," Biolinguistics, 2007, 1:9-27, for the claim that finite automata and their inadequacy entered into his presentation of his work only with Syntactic Structures and "only because it was essentially notes for courses at MIT, where their adequacy was taken for granted" (p. 11).

${ }^{21}$ Noam Chomsky, rev. of Charles F. Hockett, A Manual of Phonology, Int. J. Amer. Ling., 1957, 23:223-234, on p. 225; and Hockett, Manual of Phonology (cit. n. 12), pp. 2 and 172 (for "hocus-pocus"), 12 (on improving on Bloomfield). The tendency of American linguists of the early 1950s to discuss hypothetical versus inductive methods for discovering linguistic structure in terms of "hocus-pocus" versus "God's truth" derives from the influence of a review by F. Householder of Harris's 1951 book Methods in Structural Linguistics, published in the International Journal of American Linguistics (1952, 18:260-268). Hockett now tends to be bracketed with Harris as the premier hocus-pocus linguists of their post-Bloomfield, pre-Chomsky generation-a bracketing that gains credibility when one notices how many citations to Hockett's work, admiring as well as critical, there are in LSLT and Syntactic Structures. For the pairing of Hockett and Harris see, e.g., Seuren, "Concerning the Roots of Transformational Generative Grammar" (cit. n. 11), p. 105; and Koerner, "Chomskyan 'Revolution' and Its Historiography” (cit. n. 6), pp. 121-129. In the bibliography of Syntactic Structures the best-represented authors, with five items each, are Harris and Hockett. 
HOCKETT'S BEHAVIORISM AS A

TARGET OF THE REVIEW OF VERBAL BEHAVIOR

There is not a whiff of antipathy to behaviorism, whether Bloomfield's or anyone else's, in LSLT or Syntactic Structures. The earlier work is more expansive on points of philosophy; and we find there, for example, a passage where Chomsky defends what he calls "Bloomfield's program of avoiding mentalistic foundations for linguistic theory." That program had come in for criticism from a linguist impressed with how philosophers such as Willard Quine and Carl Hempel had recently relinquished, as unreachable, the goal of reducing all terms in meaningful statements to nothing but the actions appropriate to their verification. The lesson for the sciences, it seemed, was that theoretical terms were bound to remain less than fully defined empirically. Should not linguists, then, readmit the mentalistic terms that Bloomfield, in reductionism's grip, had cast out? Wrong lesson, countered Chomsky. "The fact that a certain general criterion of significance has been abandoned," he wrote, "does not mean that the bars are down, and that 'ideas' and 'meanings' become proper terms for linguistics, any more than it means that ghosts are proper concepts for physics." Indeed, Chomsky continued, it will be a mark of the soundness of whatever future theory of significance is agreed upon that it "will rule out mentalism for what were essentially Bloomfield's reasons, i.e., its obscurity and general uselessness in linguistic theory."22

Chomsky sent Syntactic Structures to the press in August 1956. He submitted his review of Verbal Behavior for publication in October 1958. In between came a much less celebrated review in which, as we have seen, he raised doubts both about whether stimulus-response learning theory, of the sort exalted in Hockett's Bloomfieldian linguistics, was empirically testable and about how well a learning-theory perspective on language comported with the results of transformational analysis. Both of these criticisms took on new and ferocious life in the review of Skinner's book. Once again, however, it was Bloomfield's behaviorism that was in the dock, as Chomsky explained to the editor of Language in a letter accompanying the typescript of the review:

It [Verbal Behavior] presents the kind of treatment of language that will always appeal to many linguists, particularly those who are influenced by the general tenor, if not the details of Bloomfield's behaviorism and "anti-mentalism." Since behaviorism has been such an important part of recent thought, and since this book is after all the only serious attempt to discuss linguistic behavior in the manner which has been claimed possible and necessary, it seemed to me appropriate to give it very serious attention. ${ }^{23}$

\footnotetext{
${ }^{22}$ Chomsky, LSLT, I-19 and I-20 (frames 22 and 23), responding to Rulon S. Wells, "Meaning and Use," Word, 1954, 10:235250. The locus classicus of the critique of reductionism is Willard van Orman Quine, "Two Dogmas of Empiricism" (1951), rpt. in Quine, From a Logical Point of View (Cambridge, Mass.: Harvard Univ. Press, 1953), Ch. 2. Chomsky (LSLT, I-20) cited another essay in that collection, "The Problem of Meaning in Linguistics," as drawing the right lesson about significance. On the behaviorist and positivist cast of LSLT as a legacy from Chomsky's studies with Harris see Seuren, "Concerning the Roots of Transformational Generative Grammar," p. 105. On the expunging of the antimentalism of LSLT in the version Chomsky published in 1975 see Koerner, "Chomskyan 'Revolution' and Its Historiography," pp. 131-132, citing and quoting from an unpublished MS from 1984 by Iain A. Boal, "Chomsky and the State of Linguistics." On the absence of overt mentalism in Syntactic Structures see Harris, "Chomsky's Other Revolution” (cit. n. 19), esp. p. 245.

${ }^{23}$ The preface to Chomsky, Syntactic Structures (cit. n. 11), is dated 1 Aug. 1956 (p. 7). For the letter accompanying Chomsky's submitted review see Noam Chomsky to Bernard Bloch, 27 Oct. 1958, Box 4, Folder 27, Bernard Bloch Papers (MS 1129), Manuscripts and Archives, Yale University Library, New Haven, Connecticut; it is quoted in Murray, Theory Groups and the Study of Language in North America (cit. n. 11), p. 232. I have examined a scan of the original letter.
} 
In the review Chomsky credited Skinner with something much more momentous than authoring "the only serious attempt" to bring behaviorism to bear on language. What Skinner had done, Chomsky intimated, was to follow out the logic of the behaviorist program with unswerving fidelity. As a result, there was no longer any need to wonder whether concepts and methods that had seemingly worked so well in the animal learning laboratory would work just as well when extrapolated to human language. The verdict was in: they fell tragically short of what was needed. On the evidence of Skinner's efforts, when terms such as "stimulus," "response," and even "behavior" were stretched to cover human language, they lost all precision. In the process, meanwhile, the antimentalism of the program had quietly expired, as the stretched terms, and the new ones needed to fill the inevitable gaps, came to cover the same semantic territory as the supposedly rejected mentalistic ones. (Chomsky claimed to be at a loss to say how Skinner's "tact" differed substantially from the old "meaning and reference," except in being less clear.) No surprise, then, that, as Chomsky reported, behaviorism was on the wane in psychology, even in that part of it devoted to animal learning. The new ethologists especially wanted to know not just about the environment's shaping of the organism's behavior but also, as Chomsky put it, about "the internal structure of the organism, the ways in which it processes input information and organizes its own behavior." ${ }^{4}$

The human child as exactly such an information-processing organism, acquiring linguistic behavior organized in certain ways thanks to an internal structure, came up in connection with a survey of what ethologists and others had been learning about learning: namely, that it sometimes takes place independently of what the environment rewards. A child's learning of language, Chomsky suggested, looks like that kind of learning. Of course, he allowed, the child's environment determines what language gets learned-Chinese, or English, or whatever. But the child's genes seem to determine a capacity that, as the child matures, enables the learning of words in that language even when there is not much by way of regular reinforcement. Alongside that ability, he continued, may well arise another, for the extraction and internalization of the language's grammatical rules. Chomsky stressed the amazement we should feel when contemplating such an ability, because of what it appears to achieve and because of how that achievement typically takes place. On the transformational analysis, the internalized rules are what give the native speaker the power to produce and understand an infinite number of grammatical new sentences (which, again, are grammatical if they are rules-derivable, never mind how unlike previously encountered sentences they might be). And yet, wrote Chomsky, "the task [of acquiring knowledge of the rules] is accomplished in an astonishingly short time, to a large extent independently of intelligence, and in a comparable way by all children." What do children bring to language such that they learn what they do as they do from their linguistic environments? That, for Chomsky, was the question that plainly needed investigation. But Skinner had ignored it, offering only a familiar behaviorist picture of reinforcement learning plus "generalization." Chomsky concluded that with "a vast and unanalyzed contribution attributed to a step called 'generalization' which in fact includes just about everything of interest in this process," language acquisition under behaviorism was bound to remain mysterious. ${ }^{25}$

A long tradition of commentary - mostly, but not exclusively, the work of admirers of Skinner (even today there are many) - has highlighted a range of distortions in the review. ${ }^{26}$ Anyone

\footnotetext{
${ }^{24}$ Chomsky, rev. of Skinner, Verbal Behavior (cit. n. 1), p. 27.

${ }^{25}$ Ibid., pp. 39-44, 54-58, on pp. 57, 58.

26 The first major Skinnerian riposte was Kenneth MacCorquodale, "On Chomsky's Review of Skinner's Verbal Behavior," Iournal of the Experimental Analvsis of Behavior, 1970, 13:83-99. More recent contributions include Javier Virués-Ortega, "The Case against B. F. Skinner Forty-five Years Later: An Encounter with N. Chomsky," Behavior Analyst, 2006, 29:243-251; David
} 
who knows Skinner's book only through Chomsky's demolition will be amazed to discover, for example, that Skinner deals only in passing with language acquisition in children and not at all with operant conditioning in rats. ${ }^{27}$ No less surprising is how much of Skinner's "data" comes from poetry, plays, and novels; entirely representative is his quoting at one point from T. S. Eliot's Gerontion to show how certain word combinations can have their emotional effects independently of their ordering. (By way of corroboration, Skinner cites A. E. Housman on Shakespeare and Joseph Conrad on Lord Jim. ${ }^{28}$ Then, too, the learning theory that Chomsky attacked at length was not always Skinner's, as Chomsky admitted. ${ }^{29}$ Nor, when Chomsky did criticize distinctively Skinnerian positions, did those strike other behaviorists at the time as positions they too were inescapably committed to upholding, given the logic of behaviorism. ${ }^{30} \mathrm{All}$ of these otherwise curious and, for behaviorist psychologists, infuriating aspects of Chomsky's review become intelligible, I suggest, when we see the review as in the first instance-and as Chomsky explained in that 1958 letter-aimed not at Skinner's behaviorism but, rather, at the kind of behaviorism rife among Bloomfieldian linguists. To put the point another way: Chomsky portrayed Verbal Behavior as exposing the intellectual poverty of the previous era's behaviorism because it was that behaviorism that mattered for linguists like Hockett, whose embrace of it had led them to see in statistical information theory a promising theory of grammar.

Consider again Chomsky's lambasting of Skinner - it is the closing gesture - for attributing child language acquisition, after stimulus-response learning had instilled some of the basics, to generalization. Skinner had a lot to say in Verbal Behavior about the role of "generalized reinforcement" in the successful use of language. But for a behaviorist account of language acquisition that put generalization at the very center, we can turn to a textbook published in 1958, Hockett's Course in Modern Linguistics (within which, declared the preface, "the influence of . . . Leonard Bloomfield, will be apparent on every page"). There Hockett explicitly backed an analogical view of language acquisition, including the acquisition of grammar. The great linguistic leap for the growing child, in Hockett's view, occurs at that moment when, having learned, say, "mommy" with both a downward/declarative intonation and an upward/ interrogative intonation, but "daddy" with only a downward/declarative intonation, the child suddenly realizes that, though he or she has never heard it before, "daddy" can be turned into a question by giving it an upward intonation. "As of this first analogical coinage," wrote Hockett, "the child has begun to participate in genuine, if still highly idiosyncratic, language." From there, the child's grasp of grammatical language expands rapidly, thanks to the rewardingly

\footnotetext{
C. Palmer, "On Chomsky's Appraisal of Skinner's Verbal Behavior: A Half Century of Misunderstanding," ibid., pp. 253-267; and Barry E. Adelman, "An Underdiscussed Aspect of Chomsky (1959)," Analysis of Verbal Behavior, 2007, 23:29-34. On the vitality of Skinner's book, and indeed behaviorism, beyond Chomsky's review see Henry D. Schlinger, "The Long Good-bye: Why B. F. Skinner's Verbal Behavior Is Alive and Well on the Fiftieth Anniversary of Its Publication," Psychological Record, 2008, 58:329-337.

${ }^{27}$ On children's learning of language in the review versus the book see John E. Joseph, "How Behaviourist Was Verbal Behavior?" in From Whitney to Chomsky: Essays in the History of American Linguistics (Amsterdam: Benjamins, 2002), Ch. 8, p. 176-though his claim there that Skinner "never raises the issue" in the book is too strong; see B. F. Skinner, Verbal Behavior (New York: Appleton-Century-Crofts, 1957), p. 31, quoted in Chomsky, rev. of Skinner, Verbal Behavior (cit. n. 1 ), p. 36 n 15. On rat learning in the review versus the book see Julie Andresen, "Skinner and Chomsky Thirty Years Later; or, The Return of the Repressed," Behav. Analyst, 1991, 14:49-60, esp. p. 52.

${ }^{28}$ Skinner, Verbal Behavior, pp. 155-156.

${ }^{29}$ See, e.g., Chomsky, rev. of Skinner, Verbal Behavior (cit. n. 1), p. 39, criticizing the drive reduction theory that, he noted, Skinner too rejected.

${ }^{30}$ See esp. MacCorquodale, “On Chomsky's Review of Skinner's Verbal Behavior” (cit. n. 26).
} 
comprehending responses it receives to the analogical extensions that make sense to listeners and the frustrating lack of comprehension met with otherwise. ${ }^{31}$

Both Hockett and Bloomfield - neither of them mentioned in the Skinner review-came in for naming and shaming for their analogical treatment of language acquisition a few years later, in Chomsky's Cartesian Linguistics (1965). There they got lumped with the philosopher Gilbert Ryle and other behaviorist thinkers who, in one form or another, betrayed the Cartesian tradition of innatism and instead attempted "to account for the normal, creative use of language in terms of 'generalization' or 'habit' or 'conditioning." 32 So Hockett, loyal Bloomfieldian behaviorist, actually subscribed to the position on generalization in child language acquisition that Chomsky misleadingly excoriated Skinner for holding.

To point this out - and, more generally, to see Hockett as a target of the Skinner review - is not, of course, to suggest that the only reason Chomsky went antibehaviorist, and in the way that he did, was his developing antipathy to Hockettian linguistics. ${ }^{33}$ In the Harvard psychologist George Miller, for example, Chomsky's Cambridge circle of the early 1950s contained someone increasingly disenchanted with behaviorism in general and Skinner in particular. Nevertheless, Miller's acquaintance did not, as we have seen, mitigate the behaviorism of LSLT, completed in the same year that Miller completed his famous "magical number seven" papera soon-classic source of the cognitive-scientific picture of the human mind as an information processor with a discoverable structure and capacity. ${ }^{34}$ And where, incidentally, did Chomsky first cite that paper? The Skinner review, surprisingly enough, makes no reference to it. Its debut within Chomsky's publications was in the earlier Hockett review, where Chomsky stressed how poorly some of Hockett's assumptions in his Manual of Phonology fit the results that Miller reported on the ability of humans to identify phonemes. ${ }^{35}$ Miller's postbehaviorist work thus initially came to matter for Chomsky's linguistics in furnishing yet another stick with which to beat Hockett.

\section{HOCKETT'S DARWINISM AS A TARGET \\ OF CHOMSKY'S ANTI-DARWINIAN POLEMICS}

Within linguistics, Hockett's 1958 textbook rapidly became a classroom staple. Even Chomsky learned from it, borrowing Hockett's distinction there between "surface" and "deep" structures for, respectively, the syntax of utterances in a natural language and syntax as reconstructed along transformational generative lines. (Commentators who incline to stress Chomsky's debt to Hockett note the roots of this distinction in the latter's "Two Models of Grammatical

\footnotetext{
${ }^{31}$ Skinner, Verbal Behavior (cit. n. 27), p. 147; and Charles F. Hockett, A Course in Modern Linguistics (New York: Macmillan, 1958), pp. vii, 353-362, 425-438, on p. 357.

32 Noam Chomsky, Cartesian Linguistics: A Chapter in the History of Rationalist Thought (New York: Harper \& Row, 1965), pp. 12-13, on p. 13; see also the discursive notes on pp. 81-82.

${ }^{33}$ Previously named suspects in the mystery of whose behaviorism, if not Skinner's, was under attack in Chomsky's Skinner review include Quine and the behaviorist psychologist Clark Hull. See, respectively, Pierre Swiggers, "How Chomsky Skinned Quine; or, What 'Verbal Behavior' Can Do," Language Sciences, 1995, 17:1-18; and Murray, Theory Groups and the Study of Language in North America (cit. n. 11), p. 232.

${ }^{34}$ On Miller and Chomsky, including their first meeting in September 1954, see Harris, "Chomsky's Other Revolution" (cit. n. 19), pp. 239-241; for Miller's own recollection see the interview with him in Baars, Cognitive Revolution in Psychology (cit. n. 1), p. 207. For Miller's presentation of the "magical number seven" paper as a lecture in April 1955 see the note in George Miller, "The Magical Number Seven, Plus or Minus Two: Some Limits on Our Capacity for Processing Information," Psvchol. $\underline{\text { Rev }}$, 1956, 63:81-97. Miller also gave a talk based on the paper on the same day of the September 1956 MIT symposium where Chomsky introduced his three models of grammar. See Gardner, Mind's New Science (cit. n. 2), p. 28; and, for Miller's recollection, Miller, "The Cognitive Revolution: A Historical Perspective," Trends in Cognitive Science, 2003, 7:141-143.

${ }^{35}$ Chomsky, rev. of Hockett, Manual of Phonology (cit. n. 21), p. 232.
} 
Description," which recommended that sentences be understood as "derived" from "underlying forms to which a process has been applied.") $)^{36}$ Overwhelmingly, however, A Course in Modern Linguistics represented an approach to the subject that Chomsky had come to think of as wrongheaded. In line with that strengthening conviction, he responded with contempt to Hockett's efforts, in a final chapter entitled "Man's Place in Nature," to extend that approach in a new, Darwinian direction. ${ }^{37}$

Skinner, too, in Verbal Behavior, had closed the proceedings with some thoughts on how to integrate a behaviorist attitude toward language with a Darwinian concern to explain its origin. For Skinner, what needed explaining was less the emergence of the behavioral capacity for language in early humans than the growth of environmental circumstances - a reinforcing "verbal community" - favoring the exercise of that capacity. Little insight was to be found, he reckoned, in the dance language of the bees and other animal signaling systems studied within ethology, since these were the products not of learning but of instinct, built by natural selection. Skinner was nevertheless at pains to stress that operant conditioning and natural selection were similar processes, albeit instantiated on very different timescales, since both adapted creatures to their surroundings via the selection of effective behaviors from a repertoire of variants. ${ }^{38}$ Hockett's book did not cite Skinner's and shows no sign of acquaintance with the latter's signature views. But Hockett also emphasized a parallel between the ontogenetic and phylogenetic acquisition of language. The key notion for him was, again - and un-Skinnerishly - the innovative role of analogy. Just as children truly embark upon language only once they start analogizing, in a rewarded way, from the speech they have heard, so, Hockett conjectured, our prehuman ancestors took the first step toward language when, "by the type of analogy called blending," parts of their existing, gibbon-like calls came together in new calls that got understood, with the result that "the habit of building such new calls in time gained ground." For Hockett, the millennia of evolutionary change that followed from this beginning transformed both the hominid lineage and its communication system, making both singularly powerful, though without leaving them different in kind from what is present in the rest of nature. Among speaking humans no less than among dancing bees and courting sticklebacks, wrote Hockett, "communicative behavior is those acts by which one organism triggers another." Indeed, each of the features that, on his analysis, defined human language as a communication system - for example, its open-endedness (what Hockett called its "productivity") - can, he showed, be found somewhere else in nature (so, in bees, "a worker can report on an entirely new source of nectar"). ${ }^{39}$

\footnotetext{
${ }^{36}$ On Hockett's textbook as "a standard introduction for generations of linguists" see the biographical article by M. Brdar, "Hockett, Charles Francis (1916-2000)," in Encyclopedia of Language and Linguistics, 2nd ed., ed. K. Brown (Oxford: Elsevier, 2006), Vol. 5, pp. 362-364, on p. 363. "Surface and Deep Grammar" is the title of Ch. 29 in Hockett, Course in Modern Linguistics (cit. n. 31). The surface/deep distinction, absent from Syntactic Structures, became identified with transformational generative grammar from the mid 1960s onward, after Chomsky used it in Aspects of the Theory of Syntax (Cambridge, Mass.: MIT Press, 1965), pp. 16ff. On Hockett's 1954 paper as a precedent for Chomsky's approach see Koerner, "Chomskyan 'Revolution' and Its Historiography” (cit. n. 6), pp. 126-128, quoting from Hockett, “Two Models of Grammatical Description” (cit. n. 20), pp. 227-228 (I have omitted the emphases in the original).

${ }^{37}$ On Hockett's chapter in the context of the longer run of Darwinian debate about the origin of language see Gregory Radick, "Race and Language in the Darwinian Tradition (and What Darwin's Language-Species Parallels Have to Do with It)," Stud. Hist. Phil. Biol. Biomed. Sci., 2008, 39:359-370, esp. pp. 367-368; and, more expansively, Radick, The Simian Tongue: The Long Debate about Animal Language (Chicago: Univ. Chicago Press, 2007), esp. pp. 287-293.

${ }^{38}$ Skinner, Verbal Behavior (cit. n. 27), Appendix: “The Verbal Community," esp. pp. 462-463.

${ }^{39}$ Hockett, Course in Modern Linguistics (cit. n. 31), Ch. 64, on pp. 582, 573, 575, 577. An observation later and widely attributed to Chomsky - that human language, in contrast to animal communication systems, enables the expression of new ideas on any topic, without limit-can be found in Hockett's 1958 discussion of productivity (p. 578) and in earlier writings of his
} 
Skinner's Darwinian reflections were little noted at the time, by Chomsky or anyone else. Hockett's, however, rapidly came to define the view from modern science on the evolutionary origins of language - and for an audience stretching well beyond linguistics itself. The main conduit was a superbly illustrated article on the origin of speech he published in a 1960 issue of Scientific American on human evolution; it was much cited, and taught, thereafter. What Hockett had by then come to call the "design features" of language had grown from the seven identified in his textbook to thirteen; and a table summarizing the distribution of those features in human and nonhuman communication systems had likewise expanded. (The table remains a staple of Linguistics 101.) But the fundamental lessons remained the same: all the properties of language are found somewhere or other in the communication systems of other species, but only human language includes them all, for Darwinian reasons to do with the pressures that one hominid lineage at one time found itself under. Hockett devoted considerable ingenuity to reconstructing the steps that led to language. Noting that the call system of present-day gibbons shares nine of the design features, he argued that these likely characterized the call system of our protohominoid ancestors too, so that the challenge reduced to explaining the origin of the remaining four. That challenge in turn, he suggested, reduced to explaining the origin of productivity, since, in his view, the other three features arose more or less straightforwardly once, with the emergence of analogizing blending, a closed, no-novelty system became an open, endless-novelty one. Nor was it difficult to imagine scenarios - an increased threat from predators, say, or increased scarcity of food - that might have favored such communicative flexibility, such that groups attaining it had a better chance of survival than those that did not. ${ }^{40}$

When, beginning in the mid 1960s, Chomsky began to attack this position, he did not name it as Hockett's. But all linguistic insiders would have recognized the target, since no one else in the field had taken anything like the same amount of trouble to develop a comparative, Darwinian account of the origin of language, nor was anyone else identified so publicly with such an account. ${ }^{41}$ Once again, however, the first major strike was occasioned by the broadly similar work of someone outside linguistics: William H. Thorpe, a senior Cambridge University-based ethologist, best known for his experimental studies of instinct and learning in birdsong. In November 1965, Thorpe and Chomsky were among the participants at a conference at Princeton on brain mechanisms involved in speech and language, the proceedings of which were published a couple of years later. Thorpe opened the event with a survey of recent ethological studies of animal communication and, as he saw it, the light they threw on the nature of human language and the question of its origin. Speaking later under the title "The General Properties of Language," Chomsky began by asking whether, apropos of the earlier discussions, "it makes any sense to study, or whether there is any useful purpose served in studying, animal communication systems within the same framework as human language." His answer followed immediately: it made no sense at all; the exercise was pointless. Yes, one could characterize human language and animal communication systems in terms loose enough to

familiar to Chomsky; see, e.g., Murray, Theory Groups and the Study of Language in North America (cit. n. 11), pp. 236-237 n 10. Hockett himself credited the observation to Bertrand Russell via Rulon Wells; see Charles F. Hockett, "Animal 'Languages' and Human Language," in J. N. Spuhler et al., The Evolution of Man's Capacity for Culture (Detroit: Wayne State Univ. Press, 1959), pp. 32-39, esp. p. 33.

${ }^{40}$ Charles F. Hockett, "The Origin of Speech," Scientific American, Oct. 1960, 203:89-96; the table is on pp. 94-95. See also Hockett, Course in Modern Linguistics (cit. n. 31), p. 574.

${ }^{41}$ On Hockett's work as an expert witness for the "evolution" side in the famous Little Rock trial on the teaching of evolution in 1981 see Box 7, Folder "Ross, Alan 1981," in the Charles F. Hockett Papers, National Anthropological Archives, Smithsonian Institution, Washington, D.C. I first learned of this correspondence from Tammy Goss, who with Liz Krznarich organized Hockett's personal papers as part of a student project in library science: Tammy Goss to Gregory Radick, 9 Oct. 2011. 
bring out similarities between them, but only at the price of making lots of manifestly nonlinguistic behavior, such as walking, look language-like too, while at the same time arbitrarily and misleadingly elevating one undoubted use of language - for influencing the behavior of listeners - into language's essence. After introducing the Chomskyan linguistic basics, Chomsky in conclusion drove home the lesson for would-be Darwinian comparatists: "It seems to me that there is no significant evidence of continuity, in an evolutionary sense, between the grammars of human languages and animal communication systems." ${ }^{42}$

Note that repeated phrase "animal communication systems." It does not appear at all in Thorpe's paper. Systems-talk in relation to animal communication was Hockett's, absorbed from the Shannon-Weaver theory and used throughout his evolutionary-comparative writings, starting with his Course in Modern Linguistics (where, incidentally, he introduced his comparative table in a section entitled "Key Properties of Language"). ${ }^{43}$ In the discussion that followed Chomsky's paper in Princeton, Thorpe asked about the possibility that elements, at least, of the deep structures that Chomsky described might be present in nonhuman animals, for "otherwise the evolution of language would be almost impossible." In reply, Chomsky indicated that he was comfortable with the notion that language had not gradually evolved at all, but, in accordance with a still-undiscovered physical law, had emerged, in one go, once the brain had evolved beyond a threshold of complexity reached only with the human species. He also criticized, as irredeemably speculative, selectionist theories of language origin-theories that, in fact, Thorpe had not endorsed, though, again, Hockett had. We read in the transcript of Chomsky's response:

I think most of the discussion of evolution of language is complete hand-waving. If one wants to give an account of how some structure is evolved, you have to say something more than that a lot of possibilities were tried and this one worked out... I am not convinced of the necessity of looking to selectional processes for an explanation of the development of language. If one is looking for an evolutionary explanation of language, I frankly do not see how his problem would be simplified if he were able to discover that other animals have systems analogous to language. I think if he were to discover this he would be faced with a new mystery, namely, how these systems emerged. Adding a new mystery won't help to solve this one. ${ }^{44}$

Over the next three decades, Chomsky affirmed these views over and over again, though never more extensively than in his 1968 book Language and Mind:

\footnotetext{
42 W. H. Thorpe, "Animal Vocalization and Communication," in Brain Mechanisms Underlying Speech and Language, ed. Frederic L. Darley (New York: Grune \& Stratton, 1967), pp. 2-10; and Noam Chomsky, "The General Properties of Language [including discussion transcript]," ibid., pp. 73-88, on pp. 73, 81. On Thorpe see the biographical article by Gregory Radick, “Thorpe, William Homan," in New Dictionary of Scientific Biography, ed. Noretta Koertge (Detroit: Scribner's, 2008), Vol. 7, pp. 42-45.

${ }^{43}$ Hockett, Course in Modern Linguistics (cit. n. 31), p. 574. Cf. Shannon and Weaver, Mathematical Theory of Communication (cit. n. 13), p. 6 ("A Communication System and Its Problems"), etc. That there is often a gap between what Chomsky cites and what he is really responding to is a familiar theme among scholarly commentators on his work; see, e.g., Seuren, "Concerning the Roots of Transformational Generative Grammar" (cit. n. 11), p. 100. Be that as it may, I should record that my revisionist reading of Chomsky's work has not won over the man himself, who, on seeing an earlier version of this essay, judged the claim about Hockett as the target of the Skinner review to be a "fantasy" and denied that his "strictly Darwinian position is antiDarwinian”: Noam Chomsky to Radick, 21 Aug. 2008.

${ }^{44}$ Chomsky, "General Properties of Language" (cit. n. 42), pp. 84 (quoting Thorpe), 85.
} 
When we ask what human language is, we find no striking similarity to animal communication systems. There is nothing useful to be said about behavior or thought at the level of abstraction at which animal and human communication fall together. The examples of animal communication that have been examined to date do share many of the properties of human gestural systems, and it might be reasonable to explore the possibility of direct connection in this case. But human language, it appears, is based on entirely different principles. This, I think, is an important point, often overlooked by those who approach human language as a natural, biological phenomenon[;] in particular, it seems rather pointless, for these reasons, to speculate about the evolution of human language from simpler systems-perhaps as absurd as it would be to speculate about the "evolution" of atoms from clouds of elementary particles. ${ }^{45}$

He went on:

As far as we know, possession of human language is associated with a specific type of mental organization, not simply a higher degree of intelligence. There seems to be no substance to the view that human language is simply a more complex instance of something to be found elsewhere in the animal world. This poses a problem for the biologist, since, if true, it is an example of true "emergence" - the appearance of a qualitatively different phenomenon at a specific stage of complexity of organization. ${ }^{46}$

\section{HOW HOCKETT CAME TO PUT TOGETHER WHAT CHOMSKY PULLED APART}

So Chomsky's critique of the synthesis he discovered in Hockett's writings of the 1950s, compounding information theory, behaviorist psychology, and Darwinian evolution, emerged in a piecemeal way, without any sign at a given stage of what the next addition would look like. Chomsky's LSLT was, we have seen, an explicitly behaviorist work, in no obvious way preparing the ground for the broadside against Skinner a few years later. And though that attack drew heavily on ethological research that, in the writings of its leaders Konrad Lorenz and Niko Tinbergen (cited approvingly in the Skinner review), embraced Darwinian agendas, Chomsky within a few years began repudiating all such agendas as misguided and misguiding when it came to human language. ${ }^{47}$

\footnotetext{
45 Noam Chomsky, Language and Mind (New York: Harcourt Brace Jovanovich, 1968; enlarged ed., 1972), p. 70. Chomsky's stance as arch-skeptic about animal language in the 1970s got teasing tribute in the naming of Nim Chimpsky, one of the chimpanzees taught human sign language as part of the era's "ape language projects," as recalled in the 2011 documentary Project Nim.

${ }^{46}$ Chomsky, Language and Mind, p. 70. Although these statements typified Chomsky's remarks on human language, animal communication, and Darwinian evolution for a quarter century, he later became more open to integrating a Darwinian perspective and animal behavior studies and quite vociferous in denying that this openness marked any sort of change in his position. See, in addition to the email to me quoted in note 43, above, the exchange with John Maynard Smith under the title "Language and Evolution," New York Review of Books, 1 Feb. 1996, 43:41; Marc D. Hauser, Noam Chomsky, and W. Tecumseh Fitch, “The Faculty of Language: What Is It, Who Has It, and How Did It Evolve?" Science, 22 Nov. 2002, 298:1569-1579; Fitch, "Noam Chomsky and the Biology of Language" (cit. n. 9); and, most recently, Robert C. Berwick and Noam Chomsky, Why Only Us: Language and Evolution (Cambridge, Mass.: MIT Press, 2015).

${ }^{47}$ Chomsky, rev. of Skinner, Verbal Behavior (cit. n. 1), pp. 26-27 and 43 (citing Tinbergen), 41 and 51 (citing Lorenz). On the emergence and-by 1959-fragmentation of ethology see Richard W. Burkhardt, Jr., Patterns of Behavior: Konrad Lorenz, Niko Tinbergen, and the Founding of Ethology (Chicago: Univ. Chicago Press, 2005). Lorenzian “imprinting," with its emphasis on how individual behavior arises through the interaction of genetically determined instinct and environmental stimuli, and its related concern with the "critical periods" when certain kinds of learning need to take place if the individual is to thrive, ever after remained the model for Chomskyan explanations of how children acquire language.
} 


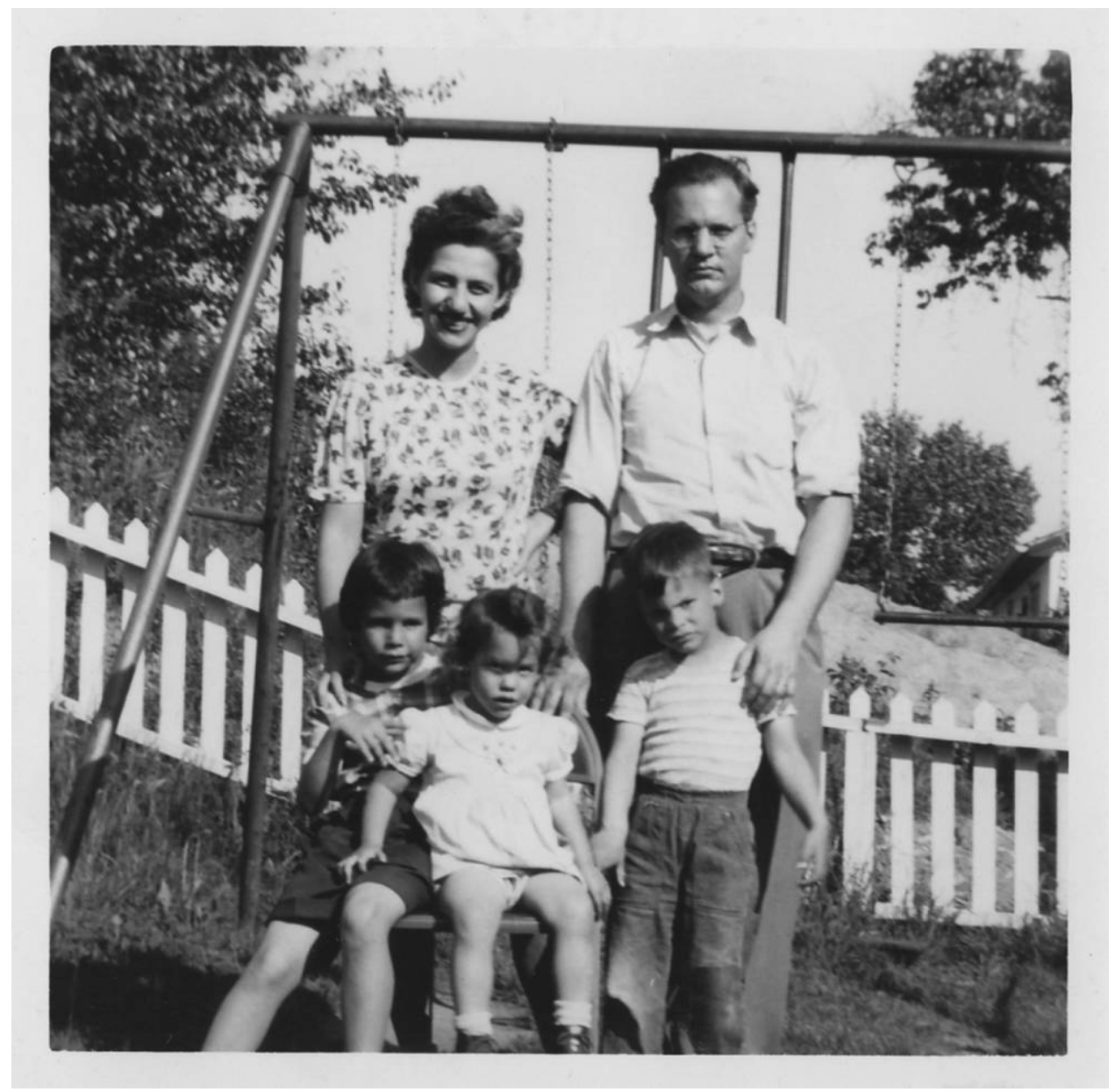

Figure 2. Charles Hockett, his wife Shirley, and three of their children in the 1950s. Provided by Tammy Goss. Now in the Hockett Papers, Box 10, Folder "C. F. Hockett portraits and family 1960-1981."

By contrast, the program that Chomsky came to define his own against-Charles Hockett's - came into being as the fulfillment of a plan spelled out in some detail from the start. That plan took public form in an article in the American Scientist in 1948. Hockett was then in his early thirties and recently arrived in the linguistics department at Cornell (see Figure 2). He had not published much up to that point, and what he had published was in the main narrowly empirical (he had become expert as a graduate student in an American Indian language, Potawatomi) or connected with his work during the war designing materials for the speedy learning of Chinese. Now, under the title "Biophysics, Linguistics, and the Unity of Science," he revealed extraordinary depths of scientific ambition and philosophical learning. He began by distinguishing two kinds of scientific unity. One arose as scientists, whatever their field, agreed to restrict their statements to predictive hypotheses couched in operationally defined terms, on the view that, for scientific purposes, only such statements were meaningful. That positivist ideal was increasingly widespread. But there was another level of unity, more haltingly achieved, that required scientists to seek to make their statements consistent with those 
in neighboring fields and to look in particular for possibilities for "reduction" - that is, for the translation (and, so, explanation) of statements of lesser generality into the terms of a field whose statements have greater generality. When it came to the reduction of biological statements to physical ones, the work was, Hockett reckoned, well under way, with a dedicated disciplinary name ("biophysics") and, in D’Arcy Thompson's On Growth and Form (1917), a superb model for the extension of mathematico-dynamic analyses to biological phenomena. When it came to the further reduction of social science statements to biological statements, however-and, so, the doing away with talk of "mind," "human nature," and so on as explanatory concepts-he judged the situation much less satisfactory. For one thing, there was not even a disciplinary name. So he proposed one, aiming to bring out the parallelism with biophysics: "sociobiology." For another, the social sciences - still relatively new - had proved very difficult to do well and, especially, to mathematize. Nevertheless, the study of speech was emerging as a productive focus, since language mattered so much, and in so many ways, to every human community and since speech, as Bloomfield had shown, lent itself so well to reductive explanation, as the upshot of conditioned responses and aspects of the central nervous system. "To the extent that various phases of peculiarly human behavior ... can be 'explained' in terms of language, which in turn is 'explained' in terms of conditioned response and the specific structure of the human organism," wrote Hockett, "a part of the problem of sociobiology can be regarded as solved." But the solution needed further development, and linguists had a central role to play. ${ }^{48}$

Although the form of the argument was new, the content, Hockett later judged, was straight out of Bloomfield. His Language was used as a textbook in the linguistics course Hockett took while an undergraduate at Ohio State University in 1933, the year of the book's publication. ${ }^{49}$ As Bloomfield had explained in his preface, it was a book informed throughout by his having learned the hard way that linguists did well to avoid tying their findings to ever-changing trends among psychologists concerned with mental life (the "mentalists") and should instead adopt the point of view of their opponents (the "mechanists"). Accordingly, after a first chapter surveying the history of linguistic science, the second chapter introduced what Bloomfield regarded as the appropriate object of linguistic inquiry: a normal speech situation, analyzed as the product of complex nervous systems conditioned to respond in different ways to different stimuli. Jill is hungry, sees an out-of-reach apple (which resembles others that have satisfied her hunger in the past), sees Jack (who has been kind to her in the past), and responds with vocal movements acquired, like all her speech, as habits gradually taken on and perfected within her speech community. The resulting vibrations in the air reach Jack's eardrums, which in turn stimulate his similarly educated nervous system, triggering limb movements that ultimately bring about his getting the apple and his giving it to Jill. So thoroughly did Hockett absorb this behaviorist-biologistic perspective on language that his 1936 M.A. thesis, although ostensibly on Greek philology and philosophy, began with an introduction that, he later wrote, "clearly showed the Bloomfieldian impact: I had grasped the significance of analogy, and proposed analogically conditioned trial and error as the mechanism not only of speaking but of all human (and even organic) action." ${ }^{10}$

\footnotetext{
${ }^{48}$ Charles F. Hockett, "Biophysics, Linguistics, and the Unity of Science," rpt. in Hockett, View from Language (cit. n. 14), pp. 1-18, on p. 15 (first published in American Scientist, 1948, 36:558-572) (subsequent citations will be to the reprinted version). For Hockett's biography see Brdar, "Hockett" (cit. n. 36); and, for more extensive coverage, James W. Gair's obituary, "Charles F. Hockett," Language, 2003, 79:600-613. For Hockett's bibliography up to 1976 see Hockett, View from Language, pp. 323-329.

${ }^{49}$ See Hockett's prefatory comment to the reprinting of "Biophysics, Linguistics, and the Unity of Science," p. 1.

${ }^{50}$ Ibid. For Bloomfield's text see Leonard Bloomfield, Language (London: George Allen \& Unwin, 1935) (this reprints, with minor variations, the American publication of 1933), pp. vii, 22-34. It is conventional to say of Bloomfield that, whereas his
} 
After graduate studies at Yale (1936-1939), Hockett spent time as a postdoctoral student at the University of Chicago, which was home both to Bloomfield and to the Unity of Science movement, recently transplanted from Central Europe. Given his views, Bloomfield was a Unity of Science natural, and in 1939 he published a slim volume on language in the movement's great publishing project, the International Encyclopedia of Unified Science. "Among the special branches of science," Bloomfield declared near the end of Linguistic Aspects of Science, "[linguistics] intervenes between biology, on the one hand, and ethnology, sociology, and psychology, on the other: it stands between physical and cultural anthropology." 51 The unificatory aims of Hockett's 1948 manifesto, then, no less than its behaviorism, betokened his Bloomfieldian training and allegiance.

His talk of "communication systems," however, came post-manifesto-and from a source some distance intellectually from the biologically grounded linguistics where he seemed to be heading in 1948. That year saw the publication of the MIT mathematician Norbert Wiener's Cybernetics and, in the Bell System Technical Journal, the Bell Labs engineer Claude Shannon's "Mathematical Theory of Communication" - an article that became much better known as part of the 1949 book under the same title that incorporated an accessible commentary from the polymathic head of the Rockefeller Foundation, Warren Weaver. "These struck me as genuinely new and as important," Hockett later recalled. "There had to be implications for linguistics and anthropology, and I set out to discover what they were." His self-education in the abstract, probability-saturated analysis of message encoding, transmission, and decoding along telephonic lines (literal and figurative), and in associated concepts such as noise, channel capacity, and information, took an important step forward in the summer of 1951, when he participated in an intensive summer school on communications theory at MIT. ${ }^{52}$ In 1952 he made a linguistically directed contribution in his own right, with a short paper in Philosophy of Science on the quantification of "semantic noise" (arising, he explained, from "a discrepancy between the codes used by transmitter and receiver"). ${ }^{53}$ In 1953, as noted, he attempted to bring other linguists on board with a long essay in Language on Shannon and Weaver's book that set out the basic theory accessibly and outlined a range of possible applications within linguistics. The "tactics-box" model of grammatical speech touched on there received fuller statement-and information theory as a whole more full-throated advocacy-two years later

Introduction to the Study of Language (1914) reflected the Wundtian psychology of its day, Language-offered as a revision of the former work - reflected the Wundt-rejecting behaviorism of its day, in part owing to Bloomfield's overlapping at Ohio State in the 1920s with the behaviorist psychologist Albert Weiss. See, e.g., Bernard Bloch's obituary, "Leonard Bloomfield," rpt. in Portraits of Linguists: A Biographical Source Book for the History of Western Linguistics, 1746-1963, 2 vols., ed. Thomas A. Sebeok (Bloomington: Indiana Univ. Press, 1966), Vol. 2, pp. 508-521, esp. p. 511. On how and why the conventional view needs qualification see Charles C. Fries, “The Bloomfield 'School," in Trends in European and American Linguistics, 1930-1960, ed. Christine Mohrmann, Alf Sommerfelt, and Joshua Whatmough (Utrecht: Spectrum, 1963), pp. 196-224, esp. pp. $203-209$.

${ }^{51}$ Leonard Bloomfield, Linguistic Aspects of Science (International Encyclopedia of Unified Science, Vol. 1, no. 4) (Chicago: Univ. Chicago Press, 1939), p. 55. On the Unity of Science movement see Peter Galison, "The Americanization of Unity," Daedalus, 1998, 127:45-71; and George A. Reisch, How the Cold War Transformed Philosophy of Science: To the Icy Slopes of Logic (Cambridge: Cambridge Univ. Press, 2005). On its Chicago base in the late 1930s, after the arrival of Rudolf Carnap and the launch of the encyclopedia series with the University of Chicago Press, see ibid., p. 10; on Bloomfield as based there between 1927 and 1940 see Bloch, "Leonard Bloomfield," p. 510; on Hockett's postdoctoral studies with Bloomfield in Chicago in the early 1940s see Gair, "Charles F. Hockett” (cit. n. 48), p. 600.

${ }^{52}$ Hockett, rev. of Shannon and Weaver, Mathematical Theory of Communication (cit. n. 14), pp. 19 (prefatory comment), 20 n 1). On the "Wiener-Shannon" theory, as it was known at the time, and its cross-disciplinary impact in the late 1940 s and early 1950s see Radick, Simian Tongue (cit. n. 37), pp. 270-271.

${ }^{53}$ Charles F. Hockett, "An Approach to the Quantification of Semantic Noise," Philosophy of Science, 1952, 19:257-260, on p. 257. By then, passing references to information theory had begun cropping up in his book reviews for Language-e.g., his review of André Martinet, Phonology as Functional Phonetics, Language, 1951, 27:333-342, esp. p. 337. 


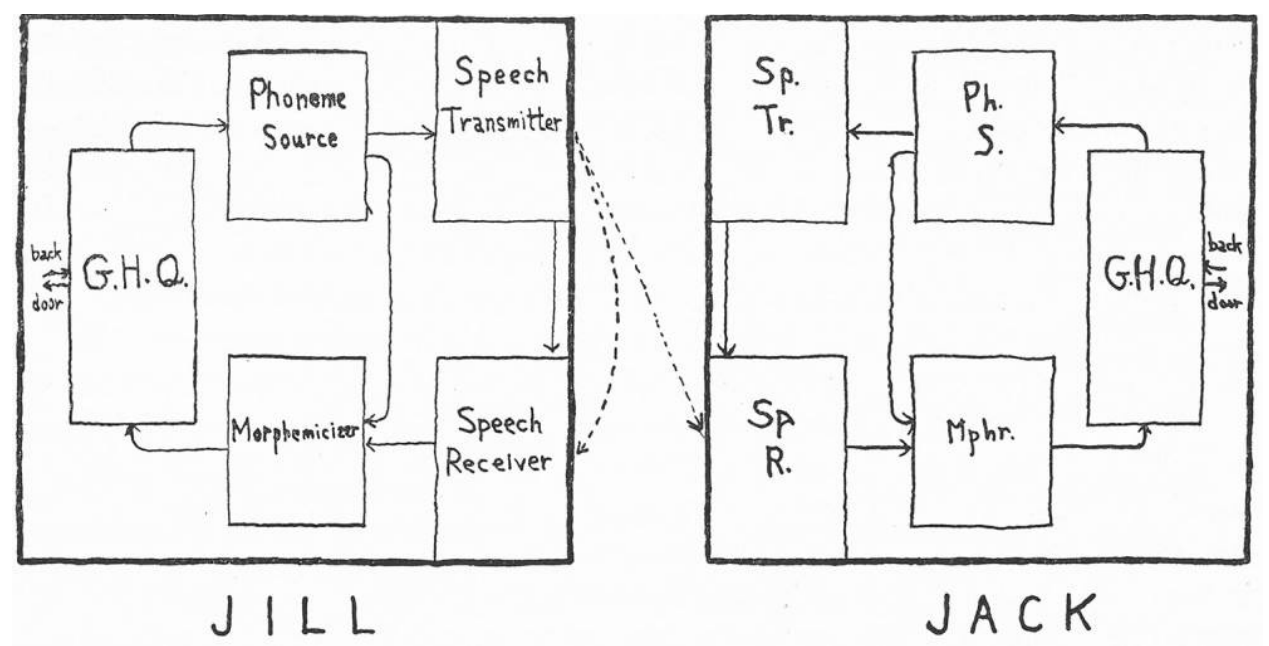

Figure 3. A "control-flow chart" schematic view of Jill speaking to Jack. From Charles F. Hockett, A Manual of Phonology (Baltimore: Waverly, 1955), p. 5.

in the introductory section of the Manual of Phonology. Along with an information-theoretic reinterpretation of Bloomfield's Jill and Jack (see Figure 3), and musings on how hardware versions of the model would speak and understand as well as flesh-and-blood people do, Hockett affirmed his behaviorism and the reductionist credentials of information theory. "It is evident," he wrote, "that a key feature of our model of a human being as a speaking animal is that it evokes the mathematically manipulable notion of probability in place of the mentalist's free will, mind, soul, or ectoplasm." ${ }^{4}$

Hockett spent the academic year 1955-1956 as a fellow at the newly established Center for Advanced Study in the Behavioral Sciences at Stanford. It was here, in the encouraging company of the likes of the anthropological geneticist James Spuhler, the cultural anthropologist and theorist of biocultural evolution Alfred Kroeber, and the ethologically inclined animal psychologist Eckhard Hess, that Hockett began educating himself in a serious way about the latest biological sciences bearing, he reckoned, on the evolutionary origins of human language..$^{55}$ Again, the first visible sign of these new - though long prepared - engagements was an essay review for Language. A number of points that Hockett would go on to develop in the final chapter of his 1958 Course in Modern Linguistics here made their debut, notably the need for clarity on, as Hockett put it in the review (under the guise of criticizing a popular book on human evolution by the archaeologist V. Gordon Childe), language's "fundamental design properties as a communicative system," the better to frame inquiry into "how it could have emerged from an earlier system which was not yet genuine language." (Hockett also took Childe to task for supposing that some human languages are more primitive than others; in the book, Hockett would explain equivalent complexity among present-day human languages as the upshot of

\footnotetext{
${ }^{54}$ Hockett, Manual of Phonology (cit. n. 12), pp. 4-14, on p. 14.

${ }^{55}$ Charles F. Hockett, prefatory comment to "Logical Considerations in the Study of Animal Communication," rpt. in View from Language (cit. n. 14), pp. 124-162, esp. p. 124.
} 
Darwinian natural selection, since, he reasoned, human groups with less complex languages would compete less effectively and so would become extinct. $)^{56}$

What politics went along with this synthetic program of Hockett's? Chomsky's way of framing the issues leads one to expect to find Hockett holding political views that are, roughly speaking, aligned with the interests of dominant elites in the midcentury United States. Yet anyone familiar with the Boasian-Bloomfieldian linguistic anthropology in which Hockett trained will know that its politics were overwhelmingly egalitarian. The same was true of the Unity of Science movement with which Hockett, following Bloomfield's lead, subsequently allied himself. ${ }^{57}$ A 1952 letter recently discovered among Hockett's papers confirms his standing, consistent with these affiliations, as a man of the Left. With McCarthyite anti-Communism ramping up, an Army official had written to Hockett-then in the reserves - that, in light of his past membership in the Communist Party, the Army was considering issuing him a dishonorable discharge unless he could explain himself adequately. Hockett's letter made the case, apparently successfully. He wrote that his connection with Communism dated back to the Depression years of the mid 1930s. Concerned to find solutions to the problems of the age, and disposed by his Quaker background to pacifism, he "became a participating Communist," he wrote, "because at the time I believed that the welfare of the people of this country, the maintenance of their fundamental rights as human beings, was more apt to be promoted through organized activity along these lines" than by any of the alternatives. He had subsequently changed his mind about Communism; but, he continued, the rights-of-man humanism that had driven him to Communism in the first place - "the fight for humanity," as he put it in the letter-remained unchanged. ${ }^{58}$

\section{LESSONS IN POLITICS, DISCIPLINARY AND OTHERWISE}

The human sciences in the Cold War United States have become the site of an increasingly sophisticated historiography, with linguistics in particular getting overdue attention of late as a key human science, integrated intellectually, institutionally, culturally, and politically with the others. ${ }^{59}$ To place Chomsky within the disciplinary matrix that nurtured him - and thus to see how the unmaking of Hockett's synthesis was the making of Chomsky's - is at once to reinforce some of the lessons of this historiography and to suggest some fresh lines of inquiry for another, still larger one.

\footnotetext{
${ }^{56}$ Charles F. Hockett, rev. of Weston La Barre, The Human Animal [and other books], Language, 1956, 32:460-469, on p. 464. For further discussion of this review and Hockett's Darwinian theorizing on race, language, and evolution see Radick, "Race and Language in the Darwinian Tradition" (cit. n. 37), p. 368.

${ }^{57}$ See Frederic J. Newmeyer, The Politics of Linguistics (Chicago: Univ. Chicago Press, 1986), pp. 39-47; and Reisch, How the Cold War Transformed Philosophy of Science (cit. n. 51), esp. Chs. 3-5.

${ }^{58}$ Charles F. Hockett, "Initial Reply to Allegations," 22 July 1952, p. 2. For a scan of this letter, along with scans of the allegationmaking letter from the Army Office of the Adjutant General (14 July 1952) and the letter informing Hockett of the favorable decision (4 Sept. 1952), I am grateful to Tammy Goss. The letters can now be found in the Hockett Papers, Box 8, Folder: "Army 1944-1957."

59 On the Cold War human sciences and their historiography generally see, e.g., Joel Isaac, "The Human Sciences in Cold War America," Historical Journal, 2007, 50:725-746; Isaac, "Introduction," in “The Human Sciences and Cold War America," special issue, Lournal of the History of the Behavioral Sciences, 2011, 47:225-231; and Mark Solovey and Hamilton Cravens, eds., Cold War Social Science: Knowledge Production, Liberal Democracy, and Human Nature (New York: Palgrave Macmillan, 2012). For recent work in this spirit on American linguistics see Janet Martin-Nielsen, “'This War for Men's Minds': The Birth of a Human Science in Cold War America," History of the Human Sciences, 2010, 23:131-155; Martin-Nielson, "A Forgotten Social Science? Creating a Place for Linguistics in Historical Dialogue," J. Hist. Behav. Sci., 201 1, 47:147-172; Martin-Nielsen, “It Was All Connected': Computers and Linguistics in Early Cold War America," in Cold War Social Science, ed. Solovey and Cravens, pp. 63-78; and Jamie Cohen-Cole, "The Politics of Psycholinguistics," J. Hist. Behav. Sci., 2015, 51:54-77.
} 
To consider first the reinforced lessons: in small ways and large, the early history of the Chomskyan program in linguistics as reconstructed above bears out, and adds new dimensions to, the notion that the relationship between behaviorism and cognitivism was complexly interactive. Extensions are straightforward. Take, on the side of the small, Chomsky's engagement with learning theory, absent from Syntactic Structures but spectacularly present in the Skinner review. In historical scholarship on Chomsky, the conventional thing to say on this point is what Chomsky has said: that it was his fellow linguist Robert Lees's 1957 review of Syntactic Structures that first identified learning theory as a next horizon, since stimulus-response learning did not seem able to account for grammatical speech in children far too inexperienced to have arrived at the rules by induction (the "poverty of the stimulus" argument, as it came to be known) ${ }^{60}$ But when one looks at the relevant sources, one finds two large problems with this story. The first is that Chomsky did, in fact, deal with the learning of grammar analyzed along transformational generative lines before Lees's review, not in Syntactic Structures but in the unpublished LSLT, which Lees had read and, believing that it would soon be published, referred to in his review. The second is that what Lees in fact wrote there about Chomskyan grammar and learning theory closely follows, albeit more long-windedly, what Chomsky wrote in LSLT - and, in keeping with the rest of that work, the content in no way amounts to a ringing challenge to regnant behaviorism. Chomsky, and then Lees, merely suggested that, given a transformational generative analysis of grammar, it must be the case that, in addition to absorbing individual sentences from their environments, speakers abstract from those sentences certain structural patterns - the patterns to which new and never-before-uttered-butstill-grammatical sentences will in turn conform. ${ }^{61}$ That is a long way off from the innatism of classic, anti-Skinnerian Chomsky. But it is not too far from Hockettian "analogizing." And, indeed, well into the early 1960s Hockett welcomed Chomsky's work. ${ }^{62}$

On the side of the large, it is worth recalling how Chomsky himself-no slouch, after all, in the historiography of linguistics - historicized his program. Here he is in a 1976 interview:

Chomsky: ... In the intellectual milieu of Cambridge [Mass.] there was a great impact of the remarkable technological developments associated with World War II. Computers, electronics, acoustics, mathematical theory of communication, cybernetics, all the technological approaches to human behavior enjoyed an extraordinary vogue. The hu-

\footnotetext{
${ }^{60}$ Robert B. Lees, rev. of Noam Chomsky, Syntactic Structures, Language, 1957, 33:375_408, esp. pp. 406-408. See also John Lyons, Chomsky (London: Fontana/Collins, 1977), pp. 170-171; Noam Chomsky, interview (with subsequent editing and additions by him) with Mitsou Ronat, in Language and Responsibility (1979), rpt. in Chomsky, On Language (London: New Press, 2007), p. 113.

${ }^{61}$ Chomsky, LSLT, IV-113 (frame 138); and Lees, rev. of Chomsky, Syntactic Structures, pp. 406-408. After dilating on inductive generalization versus prediction-from-hypotheses in science, Lees suggested that, on a Chomskyan picture, grammatical speech in children must be the outcome of a process like the latter.

${ }^{62}$ For Hockett's hailing of Syntactic Structures as a "breakthrough" in a 1964 presidential address see Newmeyer, "Has There Been a 'Chomskyan Revolution' in Linguistics?” (cit. n. 6), p. 10-though Koerner, "Chomskyan 'Revolution' and Its Historiography" (cit. n. 6), pp. 129-130, detects a degree of intergenerational diplomacy on Hockett's part. For unambiguous praise by Hockett, and for a point Chomsky had made in his ungenerous review of Hockett's Manual of Phonology, see Charles F. Hockett, "Ethnolinguistic Implications of Recent Studies in Linguistics and Psychiatry" (1960), rpt. in View from Language (cit. n. 14), Ch. 6, p. 115 n 15. Hockett's eventual counterattack on Chomsky in Hockett, The State of the Art (The Hague: Mouton, 1968), was widely regarded as a disappointment-though there are some nice touches, as when Hockett asks how, except by analogy, Chomsky produced strings such as "Colorless green ideas sleep furiously" (p. 89 n 31). On Hockett's responses (including historiographic ones) to Chomsky more generally see Julia S. Falk, "Turn to the History of Linguistics: Noam Chomsky and Charles Hockett in the 1960s," Hist. Ling., 2003, 30:129-185, esp. pp. 153-161. For encounters with Chomsky, Hockett, and their peers not long after Hockett's book came out see Ved Mehta, "John Is Easy to Please," in John Is Easy to Please (London: Secker \& Warburg, 1971), pp. 175-241.
} 
man sciences were being reconstructed on the basis of these concepts. It was all connected. As a student at Harvard in the early 1950s all of this had a great effect on me. Some people, myself included, were rather concerned about these developments, in part for political reasons, at least as far as my personal motivations were concerned.

Interviewer: For political reasons?

Chomsky: Yes, because this whole complex of ideas seemed linked to potentially quite dangerous political currents: manipulative, and connected with behaviorist concepts of human nature. ${ }^{63}$

Among other things we might now want to quibble with, the passage conveys an impression, found throughout the Chomskyan oeuvre, of a unitary program at work. Books have been written about-to quote the title of one-Chomsky's system of ideas. ${ }^{64}$ Yet on the reconstruction offered here, some of the biggest ideas in Chomsky's program came into place not just piecemeal but contingently. That insight in turn engenders a deeper one, into the program's fit with Chomsky's "other" politics: the radical ones that, from the Vietnam War to 9/11 and beyond, kept him in the media spotlight. Given what we have seen of how Chomsky's scientific work came to have the character it did, and also how it might have had quite a different character, the most plausible answer to the oft-asked question of how Chomsky's science and politics go together is that the politics would likely have been the same whatever the contents of his program. His politics were a modified but never-spurned legacy of his upbringing, antedating all his scientific achievements. ${ }^{65}$ And just as transformational generative grammar can be made consistent with some versions of stimulus-response learning theory and with some versions of Darwinian evolutionary theory, so the biologically based innatism he endorsed is in many respects a much less obvious counterpart to his politics than would be a concern with the shaping powers of learning and culture. (That was even more so in America in the postwar period, when innatist ethology, on which Chomsky drew, had not fully dispelled the odor of Nazi racialism. ${ }^{66}$

These reflections point to another reinforced lesson, about the need for open-mindedness about how exclusive the ties really were between open-mindedness, considered as an American scientific-political ideal during the Cold War, and cognitive science. ${ }^{67}$ Hockett was, we have seen, a man of the Left and a committed friend of freedom, no less than Chomsky. Hockett's behaviorism was different from Skinner's; but, again, behaviorism was always a many (if not infinitely) splendored thing. Hockett's version licensed him not merely to contemplate but to insist upon a role for the psychological faculty of analogical generalization in explaining how

\footnotetext{
${ }^{63}$ Chomsky, On Language (cit. n. 60), p. 128.

${ }^{64}$ See Fred D'Agostino, Chomsky's System of Ideas (Oxford: Clarendon, 1986), esp. p. vii on the "fundamental underlying unity" of Chomsky's thought across the board. See too James McGilvray, "Introduction," in The Cambridge Companion to Chomsky, ed. McGilvray (Cambridge: Cambridge Univ. Press, 2005), pp. 1-18, esp. pp. 7-12.

${ }^{65}$ Among many discussions of connections between Chomsky's linguistics and his politics see, e.g., Lyons, Chomsky (cit. n. 60), pp. 12-15; and D'Agostino, Chomsky's System of Ideas, pp. 206-214. The continuities between Chomsky's politics and those of his parents are vivid in Barsky, Noam Chomsky (cit. n. 11).

${ }^{66}$ See Joseph, "How Behaviourist Was Verbal Behavior?" (cit. n. 27), p. 179. On the postwar suspicions about ethology see Burkhardt, Patterns of Behavior (cit. n. 47), p. 385

${ }^{67}$ On the history of that ideal see Jamie Cohen-Cole, The Open Mind: Cold War Politics and the Sciences of Human Nature (Chicago: Univ. Chicago Press, 2014), esp. pp. 147-157 on how behaviorist psychology came to be represented, in the writings of Chomsky and others, as the ideal's negation.
} 
humans acquire language. In a similar spirit, he counseled would-be phonologists that, to do their job well, they had to learn to "empathize" (his emphasis) with the speakers of the language under study, the better to make correct judgments as to what sounds the same and what sounds different. He registered no tension between these views and his programmatic stimulus-andresponse antimentalism. No wonder that, when asked about his behaviorism in later life by the historian Stephen Murray, Hockett rejected the label, while Murray rejected the rejection. ${ }^{68}$

Real behaviorism's disappearance behind a caricature is an instance of a wider phenomenon. Chomsky and his allies created a lot of new knowledge; they also created a lot of new ignorance. It is extraordinary how comprehensively ignorant about the state of American linguistics pre-Chomsky many otherwise well-informed people became post-Chomsky. Consider the philosopher John Searle's remark in 1972 that before Syntactic Structures American structural linguists were devoted to the grindingly empirical classification of linguistic elements - "a sort of verbal botany." In evidence he quoted, of all people, Hockett. ${ }^{69}$ Meanwhile, within American linguistics itself, what Hockett's cohort had taken for granted as the core of solid training in the subject-namely, a period of time spent in the field learning one of the languages of the native peoples of the Americas - was dropping away. The Chomskyans did not so much improve upon the old knowledge as replace it with new, quite different knowledge-typically at a great distance from any reservations or pueblos. "Agnotology" is the term recently introduced for the study of the production of ignorance in and out of the sciences. ${ }^{70}$ The Chomskyan story provides rich agnotological pickings. Beyond the successes in propagandizing and programming just mentioned, two features in particular merit attention as possibly throwing light on more general patterns, scarcely investigated up to now.

One is the role of deliberate noncitation in disciplinary change. It is tempting to see in Chomsky's omitting even to mention Hockett when attacking him a particularly insulting expression of intellectual combativeness from someone famously full of it. But Chomsky hardly invented the silent treatment as a mode of dealing with contemporaries and predecessors of whom one disapproves. The silent treatment may even deserve to be considered part of the traditional toolkit of disciplinary innovators. As the sociologist Andrew Abbott has noted, it is a "cultural function of disciplines ... [to] legitimate our necessarily partial knowledge. They define what it is permissible not to know and thereby limit the body of books one must have read." "11 Skinner's behaviorism, just as much as Chomsky's innatist linguistics, was wonderfully reassuring for the would-be acolyte about all that need never be inquired into further. ${ }^{72}$ In each case, the promotion of knowledge of a certain kind was inseparable from the promotion of ignorance of a certain kind; and that dual promotion made for an appealing and, in its day, successful combination. Of course historians of science have long been sensitive to

\footnotetext{
${ }^{68}$ Murray, Theory Groups and the Study of Language in North America (cit. n. 11), p. 178 n 38. For Hockett on empathic phonology see Hockett, Manual of Phonology (cit. n. 12), pp. 146-147, on p. 147. (Cf. Gardner, Mind's New Science [cit. n. 2], p. 206, where the passage is taken as a sign of an emerging crisis in behaviorist linguistics - a misleading gloss taken over from Frederic J. Newmeyer, Linguistic Theory in America: The First Quarter Century of Transformational Generative Grammar [New York: Academic, 1980], p. 17.) For a journalist's account of Hockett ca. 1970 explaining that "the trouble with Chomsky" is that he is a "mentalist," and "no good scientist talks about mind," see Mehta, "John Is Easy to Please” (cit. n. 62), p. 221. Yet, as John Joseph pointed out to me, Hockett had himself been criticized by George L. Trager for not being behaviorist enough when it came to the use of meaning in morphological analysis: John Joseph to Radick, 17 July 2015.

${ }^{69}$ John Searle, "Chomsky's Revolution in Linguistics," in On Noam Chomsky: Critical Essays, ed. Gilbert Harman (Garden City, N.Y.: Anchor, 1974), pp. 2-33, on p. 3 (first published in 1972 in the New York Review of Books).

${ }^{70}$ Robert N. Proctor and Londa Schiebinger, eds., Agnotology: The Making and Unmaking of Ignorance (Stanford, Calif.: Stanford Univ. Press, 2008); on the history of the term see pp. 27-28.

${ }^{71}$ Andrew Abbott, Chaos of Disciplines (Chicago: Univ. Chicago Press, 2001), p. 130.

${ }^{72}$ See the interview with Miller in Baars, Cognitive Revolution in Psychology (cit. n. 1), p. 206.
} 
possibilities of "Kuhn loss" and other species of forgetting in the sciences. They should make conceptual and methodological room for deliberate noncitation as well, tricky though it is to study. ${ }^{73}$

Where Hockett, from the time of the Skinner review onward, largely got the silent treatment, Skinner got anything but. Chomsky accused Skinner not merely of error but of "playacting" at science. Again, we should not exaggerate the novelty of this sort of charge. At the core of Watson's 1913 behaviorist manifesto was the complaint that, for all the trappings of experimental apparatus and quantitative data and so on, introspective psychology was not really a proper science and, indeed, was doomed to continued failure because its phenomena were not, as the phenomena of physics, chemistry, and biology were, objective. In some form or other, such aspersions may go back as far as self-consciousness about scientific methods. But the resonances in the wider culture have undoubtedly changed over time. And in American culture in the 1950s, in the wake of the Lysenko controversy, the idea of sham science-of "pseudoscience," a term that first gained wide currency then-became morally and politically freighted as never before. Pseudosciences were not even wrong; to engage them any more than required for exposure's sake was to legitimate them. Chomsky's review of Verbal Behavior was an attempted shutting down of something with, on his indictment, false pretenses to sciencean indictment he repeated in an equally damning review of a later book of Skinner's, Beyond Freedom and Dignity (1971).${ }^{74}$ Like consent in society at large, as Chomsky the analyst of mass media has taught, consensus in science has its techniques of manufacture. Among them is the authoritative consigning to allowable ignorance of what cannot be ignored outright. ${ }^{75}$

\footnotetext{
${ }^{73}$ For a pioneering treatment of noncitation in science as one of the ways that marginalized perspectives stay marginal see H. M. Collins, "Tantalus and the Aliens: Publications, Audiences, and the Search for Gravitational Waves," Social Studies of Science, 1999, 29:163-197.

${ }^{74}$ Chomsky, rev. of Skinner, Verbal Behavior (cit. n. 1), p. 39; Noam Chomsky, "The Case against B. F. Skinner," New York Review of Books, 30 Dec. 1971, pp. 18-24. See also Michael D. Gordin, The Pseudoscience Wars: Immanuel Velikovsky and the Birth of the Modern Fringe (Chicago: Univ. Chicago Press, 2012), esp. Ch. 3; on pseudoscience as coming to be understood as "that which is not science but resembles or mimics it" see ibid., p. 202 (emphases in original).

${ }^{75}$ I refer to Edward S. Herman and Noam Chomsky, Manufacturing Consent: The Political Economy of the Mass Media (New York: Pantheon, 1988).
} 